\title{
ASSESSMENT OF HEARING IMPAIRMENT RISK FROM THE POINT OF VIEW OF LONG-TERM EXPOSURE TO NOISE IN WORKING ENVIRONMENT
}

\author{
Pinosova, M.; Andrejiova, M.; Kralikova, R.; Hricova, B.; \\ LUMNITEZER, E. \& WESSELY, E.
}

Abstract: This paper deals with a proposal of assessment of hearing impairment risk from the point of view of long-term exposure to noise in a selected plant with engineering production. The measured results show that the normalized levels of noise exposure, extended by the uncertainty of measurement at the aforementioned workplaces, exceed the limits stipulated by the Slovak Government Decree № 115/2006 Coll. of Laws, and it is evident that according to the Ordinance № 448/2007 Coll. of Laws, all measured professions fall within the fourth category of work activities categorized according to the noise factor.

Key words: Acoustic Risk, Acoustic Risk Matrix, Noise Reduction Strategy
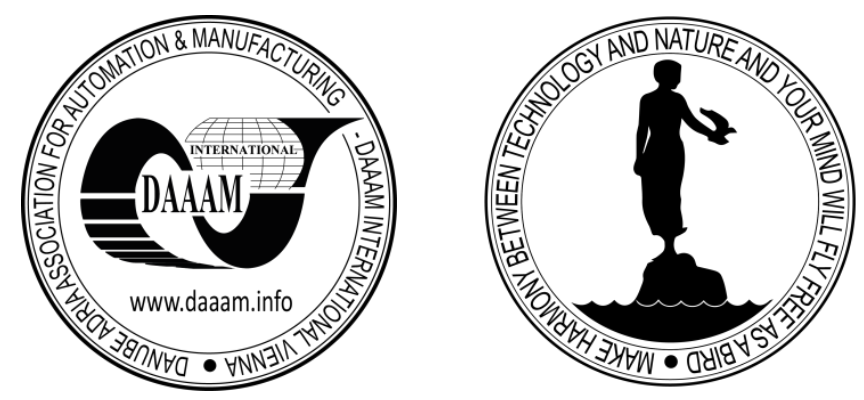

Authors' data: Ing. Ph.D. Pinosova, M[iriama]*; RNDr. Ph.D. Andrejiova, $\mathrm{M}[$ iriam]*, assoc. prof. Ing. Ph.D. Kralikova, R[užena]*; Ing. Ph.D. Hricova, B[eata]*; prof. Ing. Ph.D. Lumnitzer, E[rvin]*; assoc. prof. Ing. Ph.D. Wessely, E[mil]**; *Technical University of Košice, Faculty of Mechanical Engineering, Park Komenského 5, 04200 Košice, Slovakia, **Pod Kastielom 11, 04000 Košice, Slovakia, miriama.pinosova@tuke.sk, miriam.andrejiova@tuke.sk, ruzena.kralikova@tuke.sk, beata.hricova@tuke.sk,ervin.lumnitzer@tuke.sk,

This Publication has to be referred as: Pinosova, M[iriam]; Andrejiova, M[iriam]; Kralikova, R[uzena]; Hricova, B[eata]; Lumnitzer, E[rvin] \& Wessely, E[mil] (2015). Assessment Of Hearing Impairment Risk From The Point Of View Of Long-term Exposure To Noise In Working Environment, Chapter 30 in DAAAM International Scientific Book 2015, pp.345-358, B. Katalinic (Ed.), Published by DAAAM International, ISBN 978-3-902734-05-1, ISSN 1726-9687, Vienna, Austria DOI: $10.2507 /$ daaam.scibook.2015.30 
Pinosova, M.; Andrejiova, M.; Kralikova, R.; Hricova, B.; Lumnitzer, E. \& Wessel....

\section{Introduction}

Every day, millions of employees in Europe are exposed to noise at work and to all other risks caused by noise. The longer the employees are exposed to noise; the worse can the damage to their hearing be. Global studies highlight the fact that noiseinduced hearing loss (NIHL) (EÚ15, 2002) is recording an alarming increase, particularly among young people (Berger, 2002). Hearing loss is one of those things that will happen over time as a result of prolonged exposure to high noise levels. Once it happens, it is irreversible. In addition to hearing loss, prolonged exposure to high noise is known to cause fatigue, stress, anxiety, and depression, loss of concentration, reduced productivity, headaches and high blood pressure (Šolc, 2011).

Noise-induced hearing loss (NIHL) is one of the most common occupational diseases in countries of the European Union (Xiangdong, 2009). Damage to hearing from noise depends on a number of factors. These include the character of the noise, its frequency spectrum, its intensity and its duration. Other important aspects include the interval between the exposure and an individual's susceptibility (Alberti, 1987).

Standard ISO 1999:1990 and of the NIOSH (NOIS, 1998) guidelines recommend the exposure limit of $85 \mathrm{~dB}(\mathrm{~A})$ equivalent sound pressure level LAeq as the action level and the $3 \mathrm{~dB}$ exchange rate. That is, noise in excess of $85 \mathrm{~dB}(\mathrm{~A})$ for an eight-hour working day, i.e., a 40-hour week, is considered to be hazardous and will cause hearing loss in $5 \%$ of the population. At $90 \mathrm{~dB}$ (A) for an 8-hour workday, i.e., 40-hour week, $15 \%$ of the population will develop hearing loss due to cochlear damage (Prince et al., 1998). For every 3-dB increase in exposure level, the allowable exposure duration is halved. The EEH-based approach is generally considered appropriate for steady-state noises but not for impulsive noises (Ahroon et al., 1998). Current noise guidelines recommend integrating impulsive and continuous noises according to the EEH (NATO, 1987). For example, an exposure to a complex noise was observed to produce a much greater permanent threshold shift (PTS) and more extensive hair cell losses than an exposure to only an energy equivalent continuous or impulsive noise alone would have caused (Blakeslee et al., 1977).

Due to harmonization of legislation of the European Union, a new approach to addressing safety and health at work has been introduced into our legal system as well. One of the basic principles of this approach is the policy that for achieving a good level of safety and health at work it is not sufficient only to comply with safety regulations, but it is necessary to implement active prevention into organization of work and into working conditions. It is necessary to take into consideration, beyond the scope of the rules, what can endanger people at work; it is necessary to assess the risks (Hamernik et al., 1987). The most important European legal regulation concerning risk assessment is the Framework Directive 89/391/EEC (Buffet, 2009). Risk assessment is thus the beginning of the process of risk management. The European Agency for Safety and Health at Work (EU-OSHA) has prepared an EU-wide campaign focused on risk assessment (Buchancová et al., 2003). Its main purpose is to protect health and safety of employees. Risk assessment helps to minimize potential damage to employees, or to the environment, caused by work activity (Piňosová et al., 2013). 


\section{Materials and methods}

\subsection{Acoustic risk assessment in practice}

Evaluation of working conditions can be considered as a process that results in expertise on the degree of health risk factors in the context of the surveyed work activities. The basis of assessment of working conditions with a possible relationship to diseases and injuries to health is the assessment of potential risk factors, i.e. of their level of interaction, by observation, by analysis of job description and of work procedures, by discussing the circumstances and the manner of performance of work activities, by measuring pollutants, loading and reactions of the organism, as well as by comparing the findings with the rules, limits and recommended values. It is also essential to take into account the measure of possible tolerance and the dynamics of the state of health of workers (Provozník et al., 2000).

The most effective way of reducing noise is addressing this issue through technical means as early as at the design stage of manufacturing technologies and of facilities. A qualified approach is based on applying knowledge of technological, physical and architectural acoustics, including applications of structural modifications, directly at the source of noise. Depending on the environment of sound transmission and propagation, technical means are divided into those reducing sound transmission through the air or through machine structures and structural elements (Plura, 2001). Sinay et al. (2012) also dealt in their work with minimizing noise in the field of acoustics.

\subsection{Exposure assessment}

By exposure we understand contact of human organism with a physical, chemical, biological or any other harmful factor. Exposure assessment is a quantitative or semiquantitative assessment of a likely exposure of a man and / or of the environment to sources of risk or to a factor, from one or from multiple sources. Exposure assessment expresses a numerical estimate of exposure or of a dose that can be used for risk characterization and its quantification to human health. Exposure at work is the result of the method of using a substance or a factor, of an application and of effectiveness of technological, organizational and substitutive measures of the mode of work, of the worker's behavior, as well as of the impact of other physical and chemical factors of the environment. Exposure assessment requires a thorough analysis of work, processing of the time recording and re-measurement of exposures, primarily through personal collection of data. In case of exposures with greater variability of concentrations or of activities, it is necessary to ensure measurement over the duration of several work shifts in order to obtain objective data on the average and maximum exposure (Powazka et al., 2002).

\subsection{Noise-induced hearing loss}

The essences of damage to the auditory system, from the physiological point of view, are initially temporary and later permanent functional and morphological changes in the sensory and nerve cells of the organ of Corti in the inner ear. Epidemiological studies have shown that in $95 \%$ of the exposed population no damage to the auditory apparatus occurs, not even during a lifetime exposure to noise in the environment and in leisure activities, at the 24-hour equivalent level up to 
Pinosova, M.; Andrejiova, M.; Kralikova, R.; Hricova, B.; Lumnitzer, E. \& Wessel....

$70 \mathrm{~dB}$. However, we cannot completely exclude the possibility that people more sensitive to noise, such as children or persons who are simultaneously exposed to vibrations, could not suffer from hearing damage under such conditions. After a longterm exposure of humans who are more sensitive to noise, permanent effects, such as hypertension, may develop (Passchier-Vermeer \& Passchier, 2000). Persistent noise increases, among others, the risk of fatigue and of stress, results in high blood pressure, sleep disorders, and also causes difficulties in concentration and communication (Piňosová et al., 2012). The general conclusion of WHO is that these effects are associated precisely with long-term exposure (for 5-15 years) in the range of 65-70 dB, and more (Passchier-Vermeer \& Passchier, 2000). Adverse health effects can be minimized also by reducing noise levels below $50 \mathrm{~dB}(\mathrm{~A})$ at workplaces, where work requiring high concentration is carried out and to $65 \mathrm{~dB}(\mathrm{~A})$ at workplaces, where work of a more routine nature is done, in which communication is part of the performed work (Reinhold, 2012).

\subsection{Minimum health and safety requirements for the protection of workers from risks} resulting from exposure to noise

The scope of these regulations is to lay down minimum requirements for protection of workers from risks to their health and safety, arising or likely to arise from exposure to noise and in particular the risk to hearing. The requirements of these regulations shall apply to all activities, in which workers are exposed, or are likely to be exposed, to risks from noise as a result of their work. These regulations shall implement Directive 2003/10/EC of the European Parliament and of the Council on the minimum health and safety requirements regarding the exposure of workers to the risks arising from physical agents (noise), as follows (Dudarewicz et al., 2010)

- Exposure limit values $>\mathrm{L}_{\mathrm{EX}, 8 \mathrm{~h}}=87 \mathrm{~dB}(\mathrm{~A})$ a $\mathrm{L}_{\mathrm{CPk}}=140 \mathrm{~dB}$.

- Upper exposure action values $>\mathrm{L}_{\mathrm{EX}, 8 \mathrm{~h}}=85 \mathrm{~dB}(\mathrm{~A})$ a $\mathrm{L}_{\mathrm{CPk}}=137 \mathrm{~dB}$.

- Lower exposure action values $>\mathrm{L}_{\mathrm{EX}, 8 \mathrm{~h}}=80 \mathrm{~dB}(\mathrm{~A})$ a $\mathrm{L}_{\mathrm{CPk}}=135 \mathrm{~dB}$.

Daily noise exposure level $\mathrm{L}_{\mathrm{EX}, \mathrm{sh}}$ means the time-weighted average of the noise exposure levels for a nominal eight-hour working day as defined by international standard ISO 1999:1990 Acoustics - Determination of occupational noise exposure and estimation of noise-induced hearing impairment and ISO 9612:2009 Acoustics Determination of occupational noise exposure (Reinhold et al., 2006).

\subsection{Risk assessment procedure for noise-induced hearing loss}

Risk assessment is used for making decisions about the severity of risks and whether a given risk can be accepted or measures for addressing it shall be taken. According to (Říha, 1995) the value of risk is expressed by the functional dependence of at least two parameters, i.e.

$$
R=f(P, C)
$$

Where $P$ represents the probability of occurrence of a risk event (hazard) and $C$ is the degree of severity in case of occurrence of a risk event, e.g. affecting human health, the environment and the like. It is often expressed by assigning to it a numeric value from 1 to 5 . 
An important step in risk assessment is to determine the degree of significance of the risk and at the same time to determine the level of its acceptability. The degree of significance of a risk, in the simplest case, is the product of the scores assigned to the probability of occurrence of the risk and to the severity of risk impact, i.e. (see Table 1).

\begin{tabular}{|c|c|c|c|c|c|}
\hline \multirow{2}{*}{ Probability } & \multicolumn{6}{|c|}{ Severity of the impact of a risk event (Consequence, Impact) } \\
\cline { 2 - 6 } & Negligible & Minor & Major & Significant & Severe \\
\hline \multirow{2}{*}{ Almost certain } & 5 & 10 & 15 & $\begin{array}{c}20 \\
\text { Extreme }\end{array}$ & $\begin{array}{c}25 \\
\text { Extreme }\end{array}$ \\
\hline \multirow{2}{*}{ Highly probable } & 4 & 8 & 12 & 16 & 20 \\
& Medium & Medium & High & High & Extreme \\
\hline \multirow{2}{*}{ Probable } & 3 & 6 & 9 & 12 & 15 \\
& Low & Medium & Medium & High & Extreme \\
\hline \multirow{2}{*}{ Possible } & 2 & 4 & 6 & 8 & 10 \\
& Low & Medium & Medium & Medium & High \\
\hline Rare & 1 & 2 & 3 & 4 & 5 \\
& Low & Low & Medium & Medium & High \\
\hline Low & \multicolumn{5}{|c|}{ Low level risk } \\
\hline Medium & \multicolumn{5}{|c|}{ High level risk } \\
\hline High & \multicolumn{5}{|c|}{ Very high level risk } \\
\hline Extreme & \multicolumn{5}{|c|}{} \\
\hline
\end{tabular}

Tab. 1. The degree of risk severity

$$
R=P x C
$$

Where $P$ is the probability of occurrence of a risk and $C$ is the severity of the risk.

For fulfilling the step of risk assessment, it is necessary to construct a risk matrix. In general, this matrix is formed by combining the two basic parameters $P$ and $C$. According to (Plura, 2001), when using a five-degree risk assessment, the numeric value of 15 is the expression of an unacceptable risk.

Risk assessment allows setting priorities, to select appropriate options and it is an effective means of preventing damage to health. The process of risk assessment is similar for all factors of the working environment and it also regards living environment (Provozník, 2000).

\section{Information}

This paper presents the results of a study aimed at assessing the risks associated with acoustic noise in connection with exposure to noise at the workplace and with its possible negative effects (a risk event) to health and hearing of workers in the engineering industry.

Risk is a quantitative and qualitative expression of a danger, a degree or a level of the danger; it is a combination of the probability of occurrence of a specified phenomenon and of its consequence. Under the term of acoustic risk we understand the risk associated with exposure to noise at a workplace, which during an 8-hour time interval exceeds the limit values and action values of exposure to noise. A risk event is an event associated with a particular risk, or an event, which occurs as a result of an 
Pinosova, M.; Andrejiova, M.; Kralikova, R.; Hricova, B.; Lumnitzer, E. \& Wessel....

acoustic risk, causing damage to health and to hearing of the employees of a manufacturing plant.

Measurement of noise exposure was carried out pursuant to the Slovak Government Decree № 115/2006 Coll. of Laws, on the minimum health and safety requirements for the protection of workers from risks related to exposure to noise, as amended.

The procedure applied for the measurement was in accordance with STN EN ISO 9612.

The main sources of noise in the plant under consideration were the technological units of a cutting center (workshop) and of a welding center (workshop) and the work activities of the employees at the neighboring workplaces. The measurements were carried out at those technological installations that were in operation. The measurements were carried out so as to include at least one work cycle of the technological installations. At the workplaces in consideration, a two-shift operation was in place: the morning shift (from $6 A M$ to $2 P M$ ) and the afternoon shift (from 2 $P M$ to $10 P M$ ), with 30 minutes break for lunch. From the point of view of the relationship between the dose and the exposure to the risk factor, it was important to thoroughly process the job descriptions of the employees and the timeline of the duration of the daily exposure. The production lines in consideration were operated by operators who were working at the control consoles situated at the start and at the end of the production lines, respectively, but were also moving, for the purpose of their control, along the lines and in their immediate surroundings. The employees were not exposed to harmful factors at the start of the work shift, when work and the relevant technical documentation were prepared, the machines were set up and when planning of work was underway. A similar situation exists at the end of the work shift, when personal hygiene and cleaning of the workplaces is carried out, or when the employees leave their workplaces during personal breaks. The difference in duration of exposure to selected risk factors is also different from the point of view of the performed work profession.

Noise measurement and noise monitoring were carried out at two workshops of a mechanical engineering plant: in a "Cutting Center" (workshop) and in a "Welding Center" (workshop). The measurements were carried out at 1/3 octave band at the height of $1.5 \mathrm{~m}$ above the floor, with the microphone facing the noise source and by using the following measuring devices:

- Integrating sound level meter Nor-118 -microphone Nor-1225.

- Integrating sound level meter Nor-121 - microphone Nor-1201.

- Calibrator Nor-1251.

- Multifunction measuring instrument TESTO 400.

Conversion of noise exposure was performed for the professions: line operator at the "Cutting Center" and line operator at the "Welding Center". The workshop "Cutting Center" is located in a large one-room shop floor, where in addition to the cutting line there are also some other technological units. The "Cutting Center" is adjacent to the pressing shop. The workshop "Welding Center" is located in a large one-room shop floor adjacent to the production line "Drilling of the carrier". 
For the average values of microclimatic parameters of temperature and humidity of the working environment of both workshops see Table 2 .

\begin{tabular}{|l|c|c|}
\hline Workshop & $\begin{array}{c}\text { Line operator } \\
\text {,Cutting c. “ }\end{array}$ & $\begin{array}{c}\text { Line operator } \\
\text {,Welding c.” }\end{array}$ \\
\hline Average temperature & $21,8^{\circ} \mathrm{C}$ & $21,2^{\circ} \mathrm{C}$ \\
\hline Average relative air humidity & $34,9 \%$ & $33,1 \%$ \\
\hline Average velocity of airflow & $0,23 \mathrm{~m} / \mathrm{s}$ & $0,20 \mathrm{~m} / \mathrm{s}$ \\
\hline $\begin{array}{l}\text { Normalized level of noise exposure for work } \\
\text { category } \mathbf{L}_{\mathrm{AEX}, 8 \mathrm{~h}}\end{array}$ & $\mathrm{~L}_{\mathrm{AEX}, 8 \mathrm{~h}=85,6 \mathrm{~dB}}$ & $\begin{array}{c}\mathrm{L}_{\mathrm{AEX}, 8 \mathrm{~h}}=80,9 \\
\mathrm{~dB}\end{array}$ \\
\hline Peak level of acoustic pressure of work $\mathbf{L}_{\mathbf{C P k}}$ & $\mathrm{L}_{\mathrm{CPk}}=108,2 \mathrm{~dB}$ & $\mathrm{~L}_{\mathrm{CPk}}=107,5 \mathrm{~dB}$ \\
\hline
\end{tabular}

Tab. 2. Working conditions at the monitored workshops

\begin{tabular}{|c|c|c|c|c|c|c|c|c|c|c|c|c|c|c|c|c|}
\hline \multirow[b]{2}{*}{ Born } & \multirow[b]{2}{*}{ Workshop } & \multirow{2}{*}{$\begin{array}{c}\text { Exposure } \\
\text { (min.) }\end{array}$} & \multirow{2}{*}{$\begin{array}{c}\text { Exposure } \\
\text { (years) }\end{array}$} & \multicolumn{13}{|c|}{ Symptoms } \\
\hline & & & & 0 & 1 & 2 & 3 & 4 & 5 & 6 & 7 & 8 & 9 & 10 & 11 & 1 \\
\hline 1966 & $\mathrm{ZC}$ & 90 & 17 & $\mathrm{X}$ & & $\mathrm{X}$ & & $\mathrm{X}$ & & $\mathrm{X}$ & & & & & X & \\
\hline 1962 & $\mathrm{SC}$ & 90 & 26 & $\mathrm{X}$ & $\mathrm{X}$ & $\mathrm{X}$ & $\mathrm{X}$ & $\mathrm{x}$ & $\mathrm{X}$ & $\mathrm{X}$ & $\mathrm{X}$ & $\mathrm{X}$ & & & $\mathrm{X}$ & X \\
\hline 1956 & $\mathrm{SC}$ & 180 & 33 & $\mathrm{X}$ & $\mathrm{X}$ & $\mathrm{X}$ & $\mathrm{X}$ & $\mathrm{x}$ & $\mathrm{X}$ & & $\mathrm{X}$ & $\mathrm{X}$ & $\mathrm{X}$ & $\mathrm{x}$ & $\mathrm{X}$ & $\mathrm{X}$ \\
\hline 1979 & $\mathrm{SC}$ & 120 & 5 & & & & & $\mathrm{x}$ & & & & & & & & $\mathrm{X}$ \\
\hline 1955 & $\mathrm{SC}$ & 90 & 10 & & $\mathrm{X}$ & $\mathrm{X}$ & & $\mathrm{X}$ & & & & & & & $\mathrm{x}$ & $\mathrm{X}$ \\
\hline$\vdots$ & $\bar{\vdots}$ & $\vdots$ & $\bar{\vdots}$ & & & & & & & & e & & & & & \\
\hline 1968 & $\mathrm{SC}$ & 90 & 22 & $\mathrm{X}$ & $\mathrm{x}$ & $\mathrm{X}$ & & $\mathrm{x}$ & $\mathrm{X}$ & $\mathbf{X}$ & $\mathrm{X}$ & & & $\mathrm{X}$ & & $\mathrm{x}$ \\
\hline 1982 & $\mathrm{ZC}$ & 120 & 7 & & & & & $\mathrm{X}$ & & & & & $\mathrm{X}$ & & $\mathrm{X}$ & \\
\hline 1959 & $\mathrm{ZC}$ & 120 & 27 & $\mathrm{X}$ & $\mathrm{X}$ & $\mathrm{X}$ & & $\mathrm{x}$ & & $\mathrm{X}$ & $\mathrm{X}$ & & $\mathrm{X}$ & & $\mathrm{X}$ & $\mathrm{X}$ \\
\hline
\end{tabular}

Legend: $\mathbf{0}$ - hearing impairment, $\mathbf{1}$ - changes in blood pressure and dizziness, $\mathbf{2}$ - tinnitus, $\mathbf{3}$ - visual impairment, $\mathbf{4}$ - fatigue and headaches, $\mathbf{5}$ - unspecified respiratory distress, $\mathbf{6}$ - pain in the joints of the upper extremities, 7 - tingling of the hands, 8 - spasms of upper extremities, $\mathbf{9}$ - excessive sweating, $\mathbf{1 0}$ - change in skin color, $\mathbf{1 1}$ - problems with conversation, $\mathbf{1 2}$ - stress, SC - workshop „Cutting Center”, Z $\mathbf{S}$ - workshop „Welding Center”

Tab. 3. Symptoms of the monitored employees

The aim of the study was to examine the effect of noise exposure on human health in a selected group of employees. The objects of the research were employees who were exposed during work hours to unfavorable working environment in selected production facilities. According to the nature of the work activities of the employees in the respective production facilities and in accordance with Annex № 2 of the Slovak Government Decree № 115/2006 Coll. of Laws, Table 1, these workers fall into category of works № 4, i.e. we're performing work activities, for which noisy machines and tools are used, or which are implemented in a noisy environment with the limit value $\mathrm{L}_{\mathrm{AEX}, 8 \mathrm{~h}}=80 \mathrm{~dB}$. The participants of the research were 20 male workers in the age group from 27 to 58 years. By using a prepared questionnaire, we have obtained from the employees participating in the research necessary information about their age, duration of employment (exposure time in years), job description, daily exposure time to negative factors, we have also asked them about their sensations and health symptoms, which may appear during their working hours, and which may have negative influence on their health. All the employees participating in the research have 
Pinosova, M.; Andrejiova, M.; Kralikova, R.; Hricova, B.; Lumnitzer, E. \& Wessel.... experienced some health problems, which in their opinion were related to their professional activity, see Table 3. For basic information about the employees (age, duration of exposure, clinical symptoms) see Table 4.

\begin{tabular}{|l|c|c|}
\hline Characteristics & $\begin{array}{c}\text { Age } \\
\text { (years) }\end{array}$ & Duration of exposure (years) \\
\hline Arithmetic mean & 44,9 & 18,1 \\
\hline Standard deviation & 10,2 & 8,9 \\
\hline Max - Min & $58-27$ & $33-5$ \\
\hline
\end{tabular}

Tab. 4. Basic data of the employees

For assessment of the acoustic risk, we have used the relation $R=f(P, C)$, where $P=f\left(L_{A E X, 8 h}\right)$ is a function of the probability of exposure of a person to noise, which is determined by the normalized level of noise exposure $L_{A E X, 8 h}$ (Table 5). The probability represents the estimate of the possible occurrence of the risk of hearing impairment and of damage to health in persons exposed to noise.

The connections between the risk levels due to noise and stages of health complaints determined using the simple/flexible risk assessment method are presented in Table 5 and illustrated graphically in Figure 1.

\begin{tabular}{|l|c|c|l|}
\hline Probability & Value & Noise [dB] & Description of probability \\
\hline Rare & 1 & $<65$ & Risk occurrence is almost excluded \\
\hline Unlike & 2 & $65-75$ & Risk occurrence is unlikely, but possible \\
\hline Possible & 3 & $75-85$ & $\begin{array}{l}\text { Risk occurrence is probable (occurs } \\
\text { irregularly) }\end{array}$ \\
\hline Likely & 4 & $85-95$ & Risk occurrence is very probable \\
\hline Almost certain & 5 & $>95$ & $\begin{array}{l}\text { The danger of risk occurrence is highly } \\
\text { probable }\end{array}$ \\
\hline
\end{tabular}

Tab. 5. Basic data of the employees

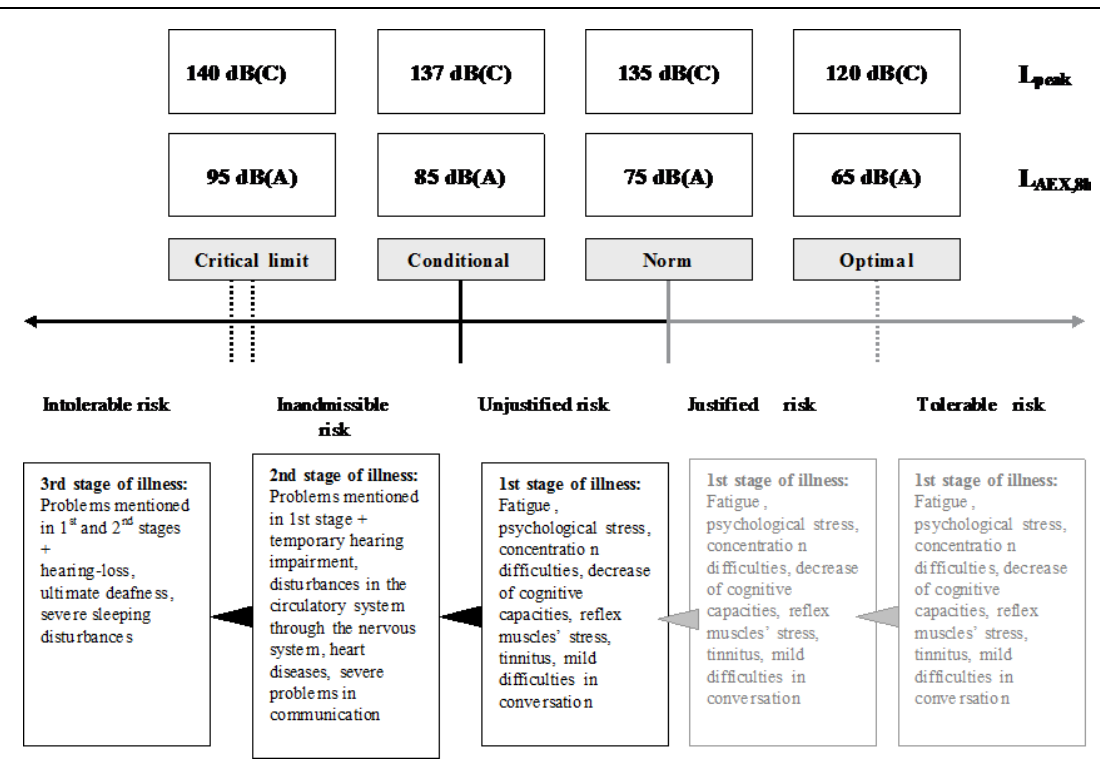

Fig. 1. Title of figure, left justified, subsequent text indented 
Consequence $C$ assesses the level and the severity of damage to health and of hearing impairment of employees that may have occurred due to acoustic risk. It is a function of consequences of the acoustic loading and causes auditory (special effects, such as acute acoustic trauma, chronic acoustic trauma and hearing loss of various degrees), extra-auditory (non-specific disorders manifested by disorders of the nervous and of the cardiovascular systems and affecting the psyche) and other (difficulties with communication, accidents, etc.) damages to the human organism (see Table 6).

\begin{tabular}{|l|c|l|}
\hline Consequence level & Value & Description of severity / consequence to hearing \\
\hline Insignificant & 1 & Without prejudice to human health and hearing. \\
\hline Minor & 2 & $\begin{array}{l}\text { Minor effect on human hearing, slight damage and } \\
\text { difficulties, such as discomfort, mild concentration } \\
\text { difficulties, changes in blood pressure and in heart } \\
\text { rate, fatigue, mental stress. }\end{array}$ \\
\hline Major & 3 & $\begin{array}{l}\text { Fatigue, tiredness, headache and dizziness / mental } \\
\text { stress / difficulty with concentration and breathing / } \\
\text { muscle pain / tinnitus / slight communication } \\
\text { problems, temporary hearing loss. }\end{array}$ \\
\hline Catastrophic & 5 & $\begin{array}{l}\text { Severe hearing loss, extreme tingling and cramping of } \\
\text { the upper extremities, serious communication } \\
\text { problems. }\end{array}$ \\
\hline $\begin{array}{l}\text { Catastrophic consequences, excessive increase in the } \\
\text { risk of hearing damage and occurrence of } \\
\text { occupational disease. This noise level should be } \\
\text { avoided in any case. }\end{array}$ \\
\hline
\end{tabular}

Tab. 6. Severity of impact of a risk event

For evaluation of the acceptability of the level of a risk event, we used the risk matrix shown below (see Fig. 2).

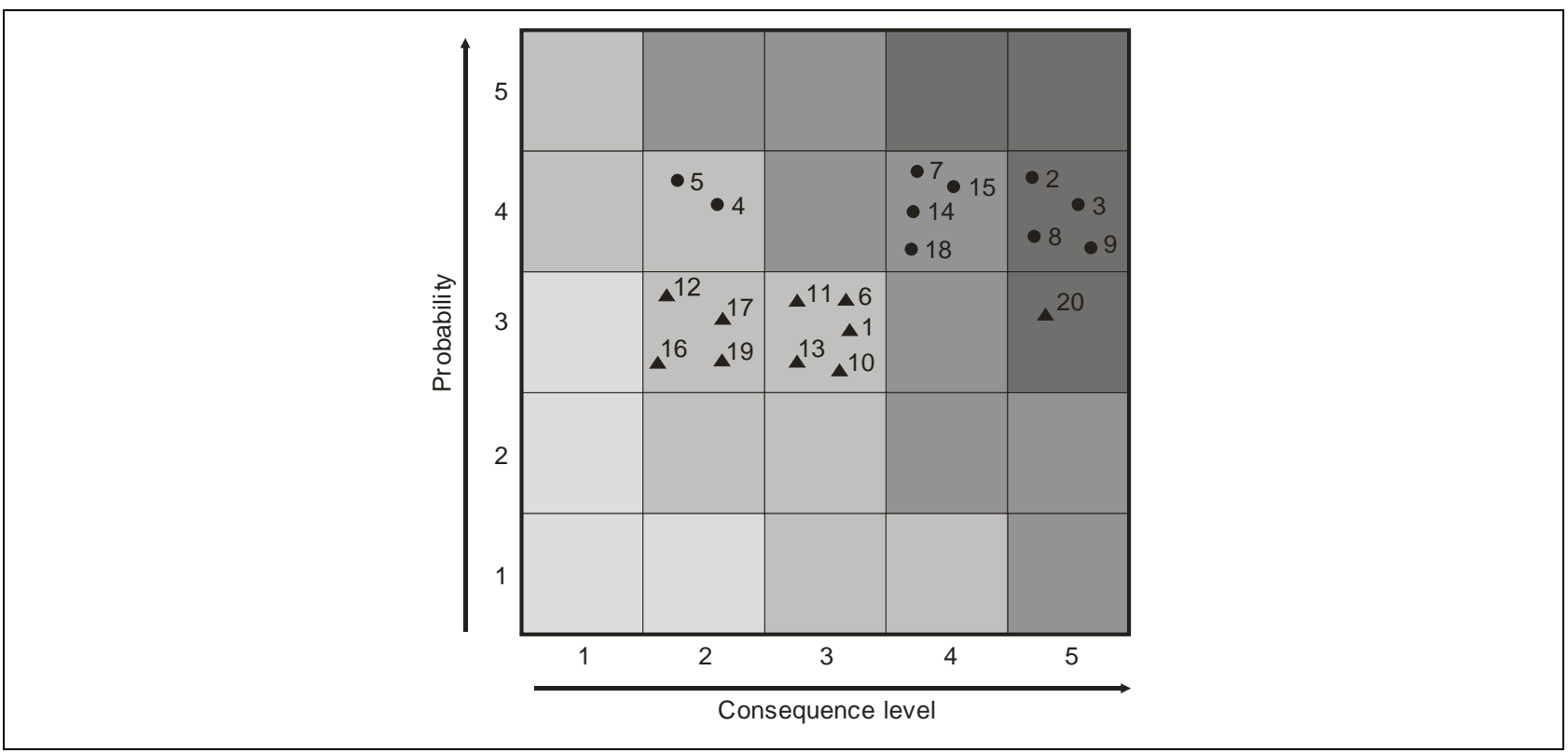

Fig. 2. Risk matrix 
Pinosova, M.; Andrejiova, M.; Kralikova, R.; Hricova, B.; Lumnitzer, E. \& Wessel....

The risk analysis shows that eight out of ten employees of the workshop "Cutting Center" work in an area of high to extreme risk severity. The average severity level of health risk assessment and of hearing impairment of the employees working in this workshop is 16 , which represents a high, undesirable risk. By contrast, almost all employees of the workshop "Welding Center" work in an area with moderate risk level (the average severity level of risk is 8 ). In both cases it is necessary to implement measures aimed at risk reduction.

\begin{tabular}{|l|c|c|}
\hline \multicolumn{1}{|c|}{ Exposure Level } & Value & Time [year] \\
\hline Negligible exposure time & 1 & $0-5$ \\
\hline Significant exposure time & 2 & $5-10$ \\
\hline High exposure time & 3 & $10-15$ \\
\hline Very high exposure time & 4 & $15-20$ \\
\hline Excessive exposure time & 5 & $>20$ \\
\hline
\end{tabular}

Tab. 7. Exposure time -the time of duration of conditions for the hearing impairment risk

\begin{tabular}{|l|l|l|}
\hline Risk level & Value & \multicolumn{1}{c|}{ Effect of risk } \\
\hline $\begin{array}{l}\text { Insignificant, } \\
\text { negligible risk }\end{array}$ & $\mathbf{1 - 4}$ & $\begin{array}{l}\text { The risk has negligible impact on human health and } \\
\text { hearing; taking of corrective actions is not required. }\end{array}$ \\
\hline Moderate risk & $\mathbf{5 - 1 0}$ & $\begin{array}{l}\text { Severity of the risk is acceptable and no special } \\
\text { measures are required. }\end{array}$ \\
\hline Tolerated risk & $\mathbf{1 1 - \mathbf { 5 0 }}$ & $\begin{array}{l}\text { The risk is still acceptable, but it is necessary to take } \\
\text { measures to reduce it. }\end{array}$ \\
\hline $\begin{array}{l}\text { Serious, } \\
\text { undesirable risk }\end{array}$ & $\mathbf{5 1 - 1 0 0}$ & $\begin{array}{l}\text { The environment is dangerous, there exist a risk of } \\
\text { severe hearing impairment, it is necessary to implement } \\
\text { very soon measures for reducing the risk. }\end{array}$ \\
\hline Unacceptable risk & $\mathbf{1 0 1}-$ & $\begin{array}{l}\text { The risk is unacceptable, persisting threat of permanent } \\
\text { hearing impairment; the activity must be suspended } \\
\text { until elimination of the risk. }\end{array}$ \\
\hline
\end{tabular}

Tab. 8. Severity level of a risk event

For comprehensive assessment and evaluation of the impact of noise on hearing and health of employees, we can use in the next step, in addition to the probability $P$ of risk occurrence and the consequence of impact $C$, also the exposure time $E$. The exposure time $\mathrm{E}$ takes into account the duration (time of exposure) of the conditions, during which the risk event affects a person and his hearing (Table 7).

As distinct from the classical definition of risk, the risk in the case of the expanded definition is a function of three parameters, $R=f(P, C, E)$ and the resulting value is expressed as the product of

$$
R=P x C \times E
$$


Where $P$ is the probability of risk occurrence, $C$ is the severity of the risk, and $E$ is the exposure time. In the case of a five-point scale of all parameters, the lowest achieved value of risk is 1 and the highest 125 . As an unacceptable risk are often regarded values in the range from 70 to 125 (Table 8).

For evaluation of the degree of risk and for assessment of mutual relations of the probability of risk occurrence $P$, of the effects on human health and hearing $C$ and of the exposure time $E$, we can use a spatial (cubic) diagram (Figure 3).

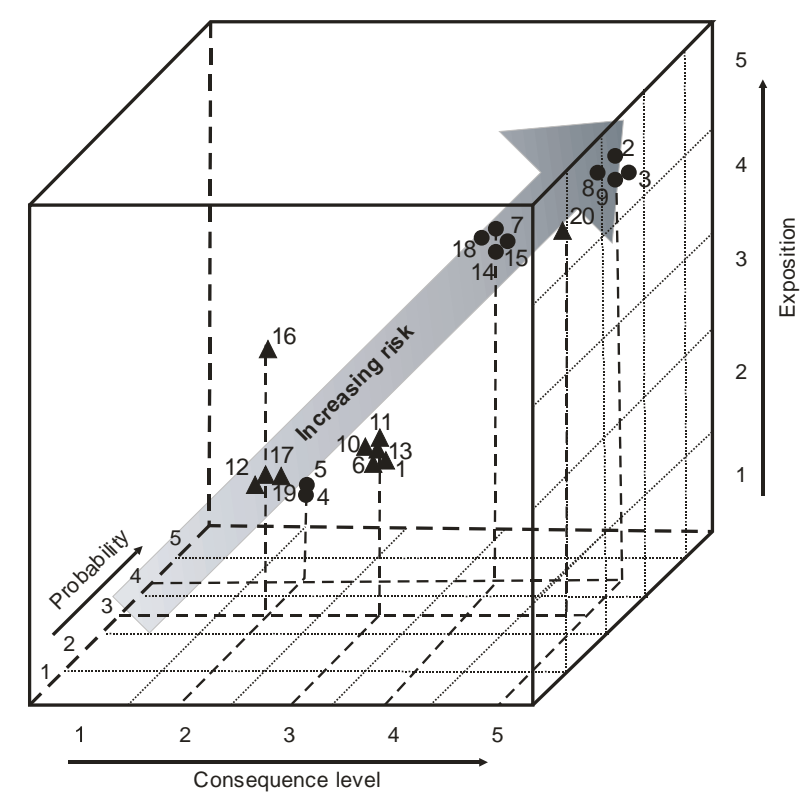

Fig. 3. Cubic matrix of risk

The results of the analysis show that nine employees from both centers work in areas of unacceptable risk (over 75). The overall average level of severity of the risk of impact on health and hearing impairment of employees, also from the point of view of long-term exposure in the workshop "Welding Center" is 28 , which is regarded as an acceptable risk. In the workshop "Cutting Center" the resulting value is as high as 76. In this case, the working environment is dangerous and there is a risk of serious undesirable hearing impairment there.

\section{Conclusion}

Health and safety at work, both for economic and for human reasons, deserve primary attention of the entire society. The quality and the level of protection of the working life and of health of the employees represent the cultural, social and economic level of development of the employers and of a respective country as a whole. Favorable working conditions may prevent and minimize the loss of human lives and damage to health due to occupational accidents, occupational diseases and other injuries to health related to work.

Evaluation of the quality of the working environment is of great importance for creating optimal conditions ensuring the comfort of man in the working environment. 
Pinosova, M.; Andrejiova, M.; Kralikova, R.; Hricova, B.; Lumnitzer, E. \& Wessel....

In the European Union, 29\% of workers are exposed to high noise levels for more than a quarter of their working time. At the same time, $20 \%$ of workers must raise their voices above normal level for at least a half of their working time. An estimated number of 39.5 million people in the European Union must speak with their co-workers by raising their voices for at least a half of their working time. Approximately $7 \%$ of workers believe that work affects their health in the form of hearing disorders. Among men the probability of hearing impairment is three times higher than among women, due to their historical employment in noisier industry sectors. Every year, 7.5 million accidents at work occur in Europe, where noise plays a role, if it is impeding communication between workers, masking the sound of danger and of the warning signals, distracting the attention of the employees and increasing work stress.

When assessing noise in the work environment, it is of primary importance to determine the type of operation in it, the types of machines and of equipment used at work, the way of addressing issues of prevention of noise pollution, the technical condition of the machines and of the equipment used at work and so on.

In our opinion, noise as such cannot actually be exactly defined, because the same noise affecting different types of people causes different results, according to the circumstances. Long-term exposure of the human organism to noise pollution can cause, in addition to hearing impairment, a wide range of other diseases. Very high levels of noise cause hearing impairment, lower levels affect the control system in our body.

Reducing noise exposure in general is one of the important tasks of modern society. Noise issues are of global importance and measures for reducing and controlling noise are globally indispensable. These measures must be based on proper scientific evaluation of available data on the effects of noise, especially in relations between dose and response. The basis for this evaluation is the process of risk assessment and of risk management.

This work can be regarded as a pilot study, which might be taken in the future as a basis for deeper analyses of some of the indicated issues. Its aim was to examine the impact of noise exposure on human health in a selected group of employees. The objects of the research were employees who were exposed to unfavorable working environment in selected production facilities during working hours. The research sample consisted of 20 male workers who are exposed to high levels of noise during their work on a long-time basis. As the negative effects of long-term exposure are revealed with a time delay, sometimes even of several years, we have decided to focus our attention in this study precisely on the assessment of risk of hearing impairment under conditions of long-term exposure to noise in working environment. We believe that this approach will help to get a clear and integrated approach to risk assessment during a long-term exposure of employees to noise during their work activity.

It should be noted that this issue is complicated and consequently there are many approaches to solving it. The methodology presented in this paper describes the view of the authors of the options for resolving this issue. The results presented in the paper are based on experience gathered up to now in the course of evaluation of environmental factors, effectively conducted by the authors. 


\section{Acknowledgements}

This work was supported by the Slovak Research and Development Agency under the contract No. APVV-0432-12. The paper was prepared with financial support from Grant Agency KEGA 039TUKE-4/2015.

\section{References}

Ahroon, W. A., Hamernik, R. P., Davis R. I. (1998). Complex noise exposures: An energy analysis. Journal Acoustical Society of America. 93, 997-1006

Alberti, P. W. (1987). Noise and the ear. Int Scott-Brown's Otolaryngology. Vol. 2. Adult Audiology. pp. 594-642

Berger, H. (2002). Active Noise Reduction (ANR) In Hearing Protection: Does It Make Sense for Industrial Applications. 27th Conference of the National Hearing Conservation Association. Dallas. Available from: http://www.aearo.com/pdf/hearingcons/anr.pdf Accessed: 2015.03.12

Blakeslee, E. A., Hynson, K., Hamernik, R. P., Henderson, D. (1977). Interaction of spectrally mismatched continuous and impulse-noise exposures in the chinchilla. Int Journal Acoustical Society of America. p. 59

Buffet, M. - A. (2009). Workforce diversity and risk assessment: ensuring everyone is covered. European Agency for Safety and Health at Work. DOI: 10.2802/11532. Available from: https://osha.europa.eu/en/publications/reports/TE7809894ENC. Accessed: 2014.03.12

Buchancová, J., a kol., (2003). Pracovné lekárstvo a toxikológia. (Occupational Medicine and Toxicology) 1. Slovenské vydanie. Vydavatel'stvo Osveta, spol. s.r.o., Martin

Dudarewicz, A., Toppila, E., Pawlaczyk-Łuszczyńska, M., Śliwińska-Kowalska, M. (2010). The influence of selected risk factors on the hearing threshold level of noise exposed employees. Archives of Acoustics. 35(3):131-42 (DOI:10.2478/v10168-0100031-3)

EÚ15 (2002). Údaje približujúce prepojenie medzi BOZP a zamestnatel’nostou (Data Approaching the Link Between Health and Safety at Work and Employability) Available from: https://osha.europa.eu/sk/topics/noise/index_html/\#_ednref2 Accessed: 2015.03.02

Hamernik, R. P., Ahroon, W. A., Henderson, D., Salvi, R. J. (1987). The interaction between continuous and impulse noise: Frequency effects. Second International Conference on the Combined Effects of Environmental Factors, Koyei, Kanazawa, Japan

NATO. The effects of impulse noise. (1987). Document AC / 243 / _PANEL8 / RSG.6_D / 9. Research Study Group RSG6/PANELS8, North Atlantic Treaty Organisation, Brussels

NOIS (1998). Criteria for a recommended standard - Occupational noise exposure. DHHS NIOSH Publication No. 98-126, U.S. Department of Health and Human Service, Canter's for Disease Control and Prevention, National Institute for Occupational Safety and Health, Cincinnati, $\mathrm{OH}$ 
Pinosova, M.; Andrejiova, M.; Kralikova, R.; Hricova, B.; Lumnitzer, E. \& Wessel....

Passchier-Vermeer, W., Passchier W. F. (2000). Noise Exposure and Public Health, Environmental Health Prespectives, 1(108):123-131

Piňosová, M., Andrejiová, M., Lumnitzer, E. (2012). Analýza klinických príznakov synergie pôsobenia hluku a vibrácií na zdravie človeka $v$ prevádzkach s ich vysokou expozíciou. Pracovní lékařství. (Analysis of clinical signs of synergy of the effects of noise and vibration on human health in plants with high levels of exposure. Occupational Medicine.) 64(2-3):103-111

Piňosová, M., Andrejiová, M., Lumnitzer, E. (2013). Analysis of clinical signs of noise exposure of human health in plants with high exposure to noise. Annals of Faculty Engineering Hunedoara: international journal of engineering. 1(11): 117-120.

Plura, J. (2001). Plánováni a neustále zlepšování jakosti. (Planning and continuous quality improvement) Praha: Computer Press. pp. 245

Powazka, E., Pawlas, K., Zahorska-Markiewicz, B., Zejda, J. E. (2002). A crosssectional study of occupational noise exposure and blood pressure in steelworkers. Noise \& Health; 5(17):15-22

Prince, M. M., Stayner, L. T., Smith, R. J., Gibert, S. J. (1998). Response to "Comments on a re-examination of risk estimates for the NIOSH Occupational Noise and Hearing Survey" Int Journal Acoustical Society of America. 103, 2736-2739

Provozník, K., Cikrt, M., Komárek, L. (2000) Manuál prevence v lékařské praxi. VIII. Základy hodnocení zdravotních rizik. (Manual of prevention in medical practice. VIII. Fundamentals of health risk assessment.) Praha

Reinhold, K. (2012). Protection of Workers against Noise at Industrial Workplace. International Conference on Electronics, Information and Communication Engineering Lecture Notes in Information Technology, Vol. 11. p. 202-207

Reinhold, K., Tint, P., Kiivet, G. (2006). Risk assessment in textile and wood processing industry. International Journal of Reliability. Quality and Safety Engineering 13(2):115-125

Ř́ha, J. (1995). Hodnocení investic na životní prostředí. Vicekriteriální analýza a EIA. (Evaluation of investments in the environment. Multicriterial analysis and EIA) Academia Praha

Sinay, J., Balážiková, M. (2012). Acoustic risk management. Journal Human Factors and Ergonomics in Manufacturing \& Service Industries. 22(3):1-10. DOI: 11.0010/hfm; Available

http://onlinelibrary.wiley.com/doi/10.1002/hfm.20376/full Accessed:2015.02.24

Šolc, M. (2011). Noise in the Occupational Environment as one of Important Factors Affecting Human Quality of Life. KIM, HF Technická univerzita v Košiciach, 7(1):8591

Xiangdong, Z., Jay, H. K., Won, J. S. (2009). Development of a noise metric for assessment of exposure risk to complex noise. Journal Acoustical Society of America. 126(2):703-712 